Article

\title{
Competitive Advantage and Its Impact on New Product Development Strategy (Case Study: Toos Nirro Technical Firm)
}

\author{
Akram Sadat Hosseini ${ }^{1}$, Sanaz Soltani ${ }^{2, *}$ and Mohammad Mehdizadeh ${ }^{3}$ \\ 1 Department of Management, Azad University of Tehran Gharb, Tehran 9176738414, Iran; \\ Akram_Hosseini2007@yahoo.com \\ 2 Department of Management, University College of Nabi Akram, Tabriz 5178868547, Iran \\ 3 Department of Management, Payam nour University of Gachsaran, Tehran 9176738414, Iran; \\ M.m135514@yahoo.com \\ * Correspondence: Soltani.sani66@yahoo.com; Tel.: +98-911-558-8057
}

Received: 18 April 2018; Accepted: 8 May 2018; Published: 26 May 2018

\begin{abstract}
Although new product development and its importance for companies as a new approach is accompanied by risks, identification of competitive advantage factors can be helpful for managers in reduction of decision-making risks. The Toos Nirro technical firm is a leading company in meeting the demands of its industry in Iran as it is one of the most effective manufacturing centers in Iran, which is committed to complying with modern standards and taking advantage of the latest scientific achievements and transfer of technology. The statistical population included experts and top managers at the Toos Niroo technical firm. The present study was conducted to identify and rate competitive advantage factors in new product development in the Toos Niroo technical firm. In addition to identification of the factors, they were also rated to reveal which factor ranked the high in new product development. This was an applied research which was carried out by a descriptive survey methodology. Using the Cochran method, a sample of 50 people was adopted and data were collected by questionnaire and analyzed using SPSS software $(p<0.15)$. Hypotheses were tested with the Kolmogorov-Smirnov and parametric tests. Results indicated that competitive advantage factors including quality, efficiency, innovation, and accountability were positively and significantly related to new product development.
\end{abstract}

Keywords: competitive advantage; new product development; quality; innovation; customer

\section{Introduction}

A firm is said to have competitive advantage when its profit rate is higher than the average rate of the related industry, and it is said to have sustained competitive advantage when it retains the high profit rate for several years. Competition issues first entered the literature when Adam Smith published his famous book entitled The Wealth of Nations. Until the late 1980s, there was no theoretical framework for the analysis, retention, and improvement of competition for a country or an industry, and thus, economic analyses were made for competition using various criteria. Throughout the 1980s, strategy books compiled by Michael were very popular in the field of competitive analysis. These books included Competitive Strategy, The Competitive Advantage of Nations, and Competitive Advantage, all of which were pressed by The Free Press in 1980, 1985 and 1989; respectively [1]. In today's dynamic environment, competitiveness is an important issue in business.

Numerous perspectives on the determinants of competitive advantage have been proposed. According to Porter (1990) [2], the profitability of firms depends on industry attractiveness and relative position of the firm in the industry. According to this notion, strategy makes an organization conduct 
activities in a distinctive way from its competitors, pivotal competences facilitate distinctiveness and diversity adoption, which ultimately provide the organization with competitive advantage [3]. The main goal of an organization in creation of competitive advantage, based on its resources and abilities, is to gain competitiveness and achieve a distinctive position regarding performance in the business market. The key for achieving competitiveness is sustainability of competitive advantages based on identification and perception of customers' demands, concentration on customer, and improvement of the process from customers' perspectives. Sustainable competitive advantage is a kind of competitive advantage which exploits organizational competences- valuable for customers, which is not easily imitated and copied by competitors, and which provides competence and competitiveness for the organization. According to most of the political, liberal, and classical economists who follow Adam Smith, the logical superiority of one's own profits over those of individual competitors, and which maximizes the profit at the same time, results in promotion of general profits and the underlying reason (i.e., invisible market hand principle) is the provision of the best product. The key factor for sustaining profitability in the modern competitive market is the possession of competitive advantage, and the necessary requirement for competitive advantage is to possess an appropriate strategy [4]. In regard to the competitive advantage, the major concern is the creation or acquisition of competitive advantage through effective integration of environmental and organizational resources using the intellectual capacities of the organization-the so called "organizational intelligence" [5].

In the real business world, products and services sold by different sellers are not of the same quality. Firms try to create distinctiveness, however slight, in their products and services in this tight competition and offer them with a higher price; however, achieving profitability this way is not very easy. Organizational intelligence is defined as utilizing the intellectual capacity of an organization to achieve its mission in a competitive environment [6].

These factors are used by competitors to transact with the partners and to provide suitable business conditions in active parameters. Naturally, there are several factors effective for the success of every firm. The first factor for the success of firms is to exploit a consistent and applicable strategy set by participation of organizational personnel around which all firm plans are designed. Other factors for promotion of the firm include pivotal quality of efficient and skillful human resources, organization and optimal exploitation of the human force, effective and continuous presence in global markets, and special attention to research projects.

Quick technological revolutions, increased risks of globalization, and privatization expectations are some of the environmental properties current organization are encountering. Factors effective and efficient in achieving competitive advantage are increasingly being paid attention to by modern organizations. Competitive advantage is achieved when the company is able to develop new products or provide services superior to those of competitors, or alternatively if they can provide the same products and services at a lower price or higher quality. This is not achieved unless the firm gains various production factors ignored by competitors. Now the question is which factors in recent decades have helped companies outpace their competitors and promote their profitability? Some advantages are obtained when a company is the first one who to use them. Other advantages, called unfair advantage, occur when a company uses them by accessing the factors inaccessible by competitors, and thus, creates competitive advantage for itself.

\section{The Concept of Competitive Advantage}

For a better understanding of each issue, they should first be defined. Obviously, if the definition is more comprehensive and more efficient, better understanding will be achieved. Some definitions of competitive advantage are presented below:

$\sqrt{ }$ Competitive advantage is the increased rate of attractiveness a firm offers compared to competitors from customers' viewpoints [7]. In the literature on competition strategy, competitive 
advantage is regarded within the framework of value creation as anything that increases income over costs [8].

$\sqrt{ } \quad$ Saaty and Vargas [9] believes competitive advantage lies in the properties or dimensions of each firm enabling it to offer better services than the competitors (i.e., better value) to customers [10].

$\sqrt{ }$ Competitive advantage is defined as the presentable values of a firm for customers so that these values outweigh the price paid by the customer [3].

According to the above definitions of competitive advantage, it seems that a direct relation between customers' expected values, values offered by the company, and those offered by the competitors determine the dimensions and conditions of competitive advantage. If the values presented by the company are closer to customers' expected values compared to the values offered by competitors, it can be said that the firm has competitive advantage over its competitors in one or more indices. This advantage makes the company superior to its competitors in proximity to customers and capturing his heart.

In different industries, some firms, regardless of whether the average profit of that industry is low or high, are more profitable than others. This superior performance is a consequence of possessing special and inimitable factors resulting in higher performance than competitors. These unique skills and capital have competitive advantage [11]. Four requirements should be met for resources and skills to be sources of sustainable competitive advantage:

$\sqrt{ }$ They should be valuable.

$\sqrt{ }$ They should be rare in existing and potential competitors.

$\sqrt{ } \quad$ They should not be easily imitable.

$\sqrt{ }$ There should be no strategic alternative for that skill or resource [12].

According to Hill and Jones [2] competitive advantage lies in the distinctiveness of features and dimensions of the company, which enables it to offer better services to customers. A schema of the origins, components, types, and results of competitive advantage is presented in Figure 1.

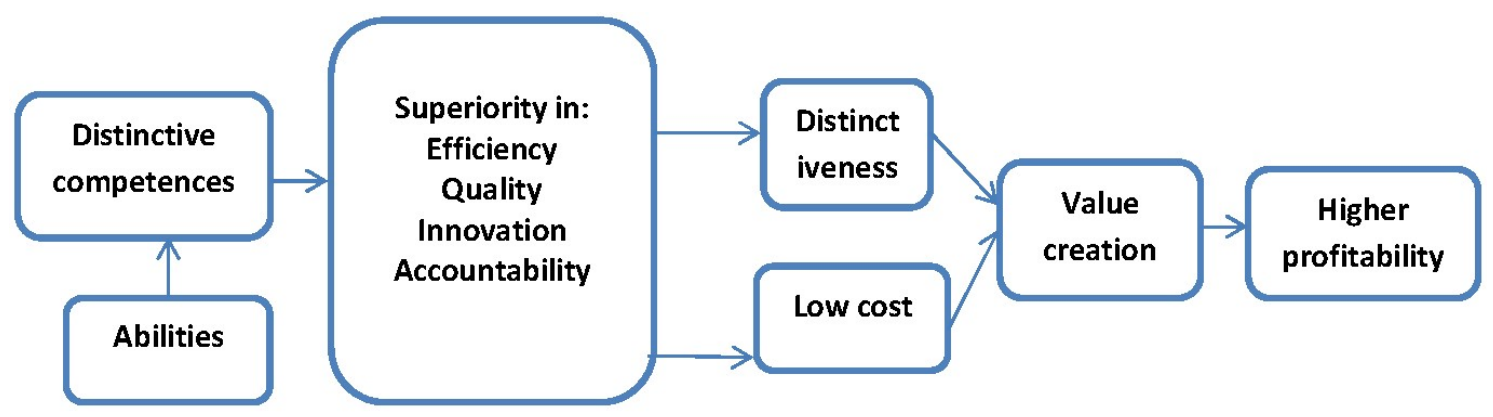

Figure 1. The roots of competitive advantage [2]. Four factors help the company to establish and retain competitive advantage, namely superior efficiency, quality, innovation, and accountability to customer. Each of these factors are the result of a distinctive competence of a firm. Indeed, they are to some extent generally distinctive competences allowing a firm to make its products distinctive, offer higher value to customers, reduce its cost structure, etc. [2].

\subsection{Efficiency and Competitive Advantage}

In an economy, different companies vary in terms of the conditions governing the selection of cost-effective strategies, which makes profit generation a natural requirement for business owners [4]. Simply speaking, business is a tool to convert inputs into outputs. Inputs are basic factors such as labor, earth, capital, management, and know-how. Outputs are the products and services a business generates. The simplest way to measure efficiency is by the amount of inputs used for producing outputs. Efficiency is the ratio of output to input. A lower amount of input used to produce a certain 
amount of output will enhance efficiency. Higher efficiency helps a company achieve competitive advantage (via low cost structure). The major component of efficiency for many firms is employee productivity, which is often measured based on the output of each employee. A firm that has the highest employee productivity usually has the lowest production cost.

\subsection{Quality and Competitive Advantage}

Quality means what the customer really wants. In the other words, a product is of high quality when it is in agreement with customers' needs and demands. Perceived quality refers to customer's judgment about the total superiority or advantage of something. Perceived quality is a form of vision related to satisfaction; however, it is not the same as vision, and results from comparing performance expectations and perceptions [13]. Higher levels of service quality lead to higher sale revenues and productivity [14]. High quality products are those products and services that are reliable, meaning that they perform well the task they were designed for, and create distinctive properties for enhancing its value for customers. When customers learn that products from one company (regarding form, properties, performance, sustainability, reliability, design, style, etc.) provide a higher value for them compared to those offered by competitors, then these products are said to be of high quality.

In fact, when a customer experiences positive emotions, higher levels of satisfaction with service are expressed [15]. High-quality products enhance a product's value before the customers and make it distinctive. This high perception of value lets the firm set higher prices for its products.

Ren et al. [16] showed that high-quality services created positive emotions in customers. Moreover, higher efficiency and lower price are achieved by high-quality products. The effect of quality on profitability is presented in Figure 2.

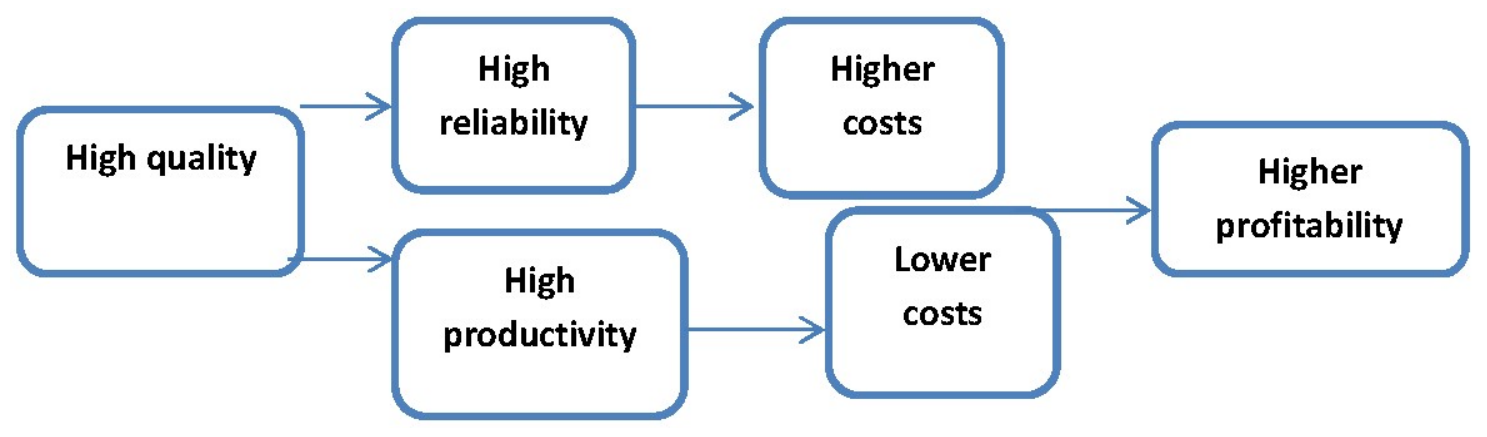

Figure 2. Effect of quality on profitability [2].

There are at least five perspectives about quality we describe here: The first vision of quality is defined as accountability to customers' demand. In this perspective, customers' demands and responding to them are the basis of an organization's orientation, and thus, is called customer-oriented quality. The second vision of quality is defined from a production perspective. In this vision, quality is tested by product comparison with a certain design or property. The third vision is a product-oriented vision. In this perspective, quality is defined as the amount of valuable properties embedded in a product. There is another vision about quality which expresses that Quality is independent of product qualities or special mental perception; however, the author added that people easily identify the quality whenever they see it. The fifth vision on quality was defines quality as the rate of the utilities of a product with suitable price (for customers) and acceptable cost (for producer ([17]. Investigation of quality visions analysis with competitiveness pattern reveals subtle but important dimensions of the relation between various quality perspectives and the success of a firm. Analysis of a customer-oriented definition with competitiveness pattern indicates that this vision well covers customer benefits, but has nothing to say about stakeholder benefits. An example in this regard is the Pan American Company, which has excellent services, suitable price, and increasing annual loss. Under this circumstance, although a customer is satisfied, the firm's power to sustain is constantly reduced, and the organization 
becomes vulnerable to unexpected events such as the September 11th attacks. The second perspective, which is production-oriented, also explicitly concentrates on the engineering dimensions of a product. This vision excludes the costs of producers, and also the costs imposed on customer by qualitative dimensions. Although this vision results in special technical and practical properties of the product, it does not necessarily lead to a firm's competitiveness and success. A product-oriented vision follows a similar competitiveness pattern, and its product will not create long-term competitiveness and success. An excellence-oriented vision typically accentuates a product's properties, though its abstract nature can challenge this and every other perception. A value-oriented vision of quality is the only perspective which simultaneously considers customers' utilities (benefit), price, and other costs for customer (i.e., customers' cost) and the producer's cost (i.e., stakeholders' benefits). This vision is not only able to create value for customers (difference of customers' benefit and cost), but also directs the organization toward retention and extension of this value as long as stakeholders' benefits are supplied [16].

\subsection{Innovation and Competitive Advantage}

Innovation can be defined as new or innovative methods used by the firm or the new products it generates. Innovation includes the creation of new products and processes. Perhaps innovation is the most important source of competitive advantage. It is innovation that stimulates competitors. Since innovation provides a firm with unique advantages (which competitors lack), it can be regarded as the main source of competitive advantage. Uniqueness enables the firm to make itself distinct from competitors and put higher prices on its products or significantly reduce its costs compared to competitors. Product innovation is the process of producing new products regarded as valuable by customers and which enhance a firm's authority on pricing. Process innovation creates value by lowering production cost.

Open innovation is a rich concept that can be implemented in many different ways by different researchers. The context dependency of open innovation is one of the least understood topics; more research is needed on the internal and external environmental characteristics affecting performance [18]. Through various case studies, Chesbrough and Crowser [19] demonstrated that open innovation has a positive effect on firm performance. Yet, most of the case studies conducted by Chesbrough were in firms that were already passing deep through the maturity stage in product life cycle.

Various factors influence the open innovation of sectors and firms. Factors outside of firms include institutions, sectors, countries, and regional innovation systems. Factors inside of firms, which give effect of to a firms' open innovation performances, include individual factors such as entrepreneurship, modular architecture, research and development (R\&D) intensity, and product life cycle. In addition, the internal open innovation attitude of a firm, which modulates the effect of open innovation on firm performance, is also an indispensable factor in the study of open innovation. With regard to the above factors, studies on various factors affecting open innovation have already been done by [20-24]. Successful companies utilize innovation and marketing activities at the same time to obtain excellent performance. The supplementary nature of innovation capacity and supply of a company's products to the market is of paramount importance. While innovation enables a company to create value and competitive advantage, marketing helps the utilization of values [25]. There is a general consensus in the literature that all types of innovation can contribute to competitive advantage.

\subsection{Open Innovation}

Open Innovation is a new paradigm that assumes that firms can and should use external ideas as well as internal ideas and internal and external paths to market, as the firms look to advance their technology. Open innovation is defined as the use of purposive inflows and outflows of knowledge to accelerate internal innovation, and extend the markets for external use of innovation, respectively [26]. With the emphasis on the importance of open innovation, there have been various studies in several 
dimensions such as firm, industry. Firstly, in the dimension of a firm, the analysis of the acquisition of technology and commercialization strategies, R\&D efficiency, corporate interactions, and strategic profit analysis, as well as technological innovation assessments show the positive effects of open innovation [27-29]. Open innovation principles allow the penetration of novel technology, products, or market landscapes which extend beyond the actual core business of firms, and which would be difficult to discover by individual organizations [30]. What are the merits of open innovation in new product development processes? Firstly, with external technology, firms can reduce costs and time [5]. When adopting open innovation, firms make use of technologies from the external market. Secondly, firms can produce new products with different resources outside. By utilizing different ideas or technologies, firms develop new unique products and differentiate with other firms.

\subsection{Accountability and Competitive Advantage}

Accountability to the customer means identifying and meeting customers' demands in a manner better than competitors, increasing the value of customers' regard for the firm's products, resulting in the creation of competitive advantage. Higher quality and innovation is an indispensable part of accountability. An important issue in accountability is customization of products and services according to special demands of customers (individual or group). The amount of time before a response to a customer is an aspect of accountability. Resources of accountability other than quality, customization, and response time include superior design, superior services, after sale services, and superior support. Suitable responsiveness to customer differentiates a company's products and services, and creates loyalty to the brand and extra pricing [31].

\subsection{The Concept of New Product Development}

New product development is a popular concept among scholars, consultants of various industries, and business schools. Achieving proficiency in new product development can help many organizations in reaching success. New product development is one of the largest powers, and at the same time, one of the most difficult activities in every business. Business managers and market philosophers believe that successful new product development is a critical factor for long-term sustainability of organizations [32]. For a definition of new product development (NPD), it should be said that NPD is a set of growth policies and activities, which through various steps of product generation for existing market places, bring about minor or major modifications to the products [33].

\subsection{Case Description}

With over three decades of experience in the production and supply of all kinds of equipment for power distribution and distribution networks, the Toos Nirro technical firm is a leading company in meeting the demands of this industry in Iran. As one of the most effective manufacturing centers in Iran which is committed to complying with modern standards and taking advantage of the latest scientific achievements and technology transfers, this company has been one of the most effective production centers in Iran by holding ten manufacturing workshops. Considering its technological approach in the field of electric power, and its development and innovation, the company draws on latest standards, scientific achievements and knowledge to transfer this technology and fulfil orders of customers with the highest quality products. The company has been successful in exporting its products to other countries by utilizing the latest technology and obtaining necessary certificates from relevant authorities, such as the Ministry of Energy and Tehran University. Quality control management plays a key role in the production process of the company. Equipped with an advanced laboratory, this unit undertakes continuous supervision over the flow of products, and these items are then transferred to the product warehouse only after the quality requirements are met. This continuous and precise monitoring system has contributed to the success of the company in obtaining essential certifications from Iranian and international authorities in Europe. The sphere of R\&D management, along with quality management, plays a key role in improving product quality, innovation, and designs 
tailored to customers' specific orders. One of the major innovations of this unit is the production of anti-theft bars for high-voltage power towers, which has been well received by most regional power companies and distribution of power [34]. In this study, the researcher also noted the willingness of the company's management to carry out such research, as well as the history of past cooperation with the company, and in view of its fundamental nature in the technological discussion of electricity.

\subsection{Research Hypotheses}

1. There is a significant relationship between efficiency and new product development.

2. There is a significant relationship between product quality and new product development.

3. There is a significant relationship between innovation and new product development.

4. There is a significant relationship between accountability and new product development (Figure 3).

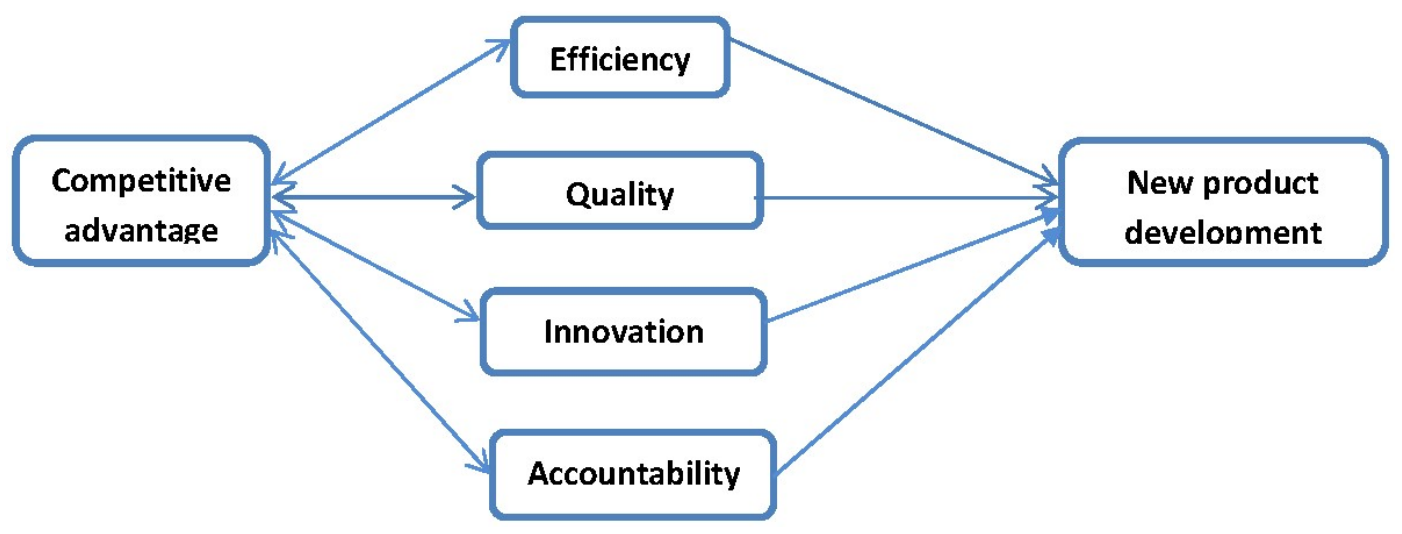

Figure 3. Conceptual model of the research.

\section{Methodology}

Adopting a methodology helps a researcher determine which method they are going to use in order to achieve the answers for research questions more exactly, more easily, and at a lower cost. Regarding the objective, the present study is a descriptive survey. This investigation is descriptive because the objective is to represent an objective, real, and regular description of the properties of a certain position or issue [35]. Meanwhile, it is a survey because it studies properties and traits of a population's individuals and investigates the current status of the statistical population in the context of some traits [36].

The methodology used in this research was selected on the basis of the existing conditions and facilities, because due to the presence of workers and factory workers at certain hours of the day, the time limits of the research, and the desire of senior managers to accelerate the collection of data and reduce costs, information gathering and time attendance at the factory, as well as compliance with environmental safety and health issues, were the most appropriate survey method.

Data were collected by documentation, the library, and observation methods. The data collection tool was a questionnaire based on the Likert Scale. Reliability of the questionnaire was determined by Cronbach's alpha which is calculated in the range of zero to one. A questionnaire is reliable when its Cronbach's alpha is higher than 0.7 , and values closer to one indicate a high reliability of the questionnaire. In this paper, the Cronbach's alpha estimated in a primary test using SPSS software was 0.85 . Content validity was used to measure the validity of the questionnaire. To ensure content validity, the questions forming the tool should introduce parts of the selected content [37]. The statistical population was defined as a number of favorable elements possessing at least one characteristic feature. Characteristic features are a feature that is common among all elements of a statistical population, and which characterizes it from other populations. The statistical population in the 
present study included 50 people in the Toos Niroo technical firm. This population included 50 experts and top managers of the Toos Niroo technical firm, ranging in age from 25 to 60 years of age, and with educational attainments of associate degrees, bachelor degrees, and Master of Science degrees, and who were related to new product development in some way. Probabilistic sampling with systematic and regular technique was used based on Vepas table for small populations $(p<0.01)$, which resulted in a sample of 50 individuals. Since the Toos Niroo technical firm has three sections, namely warehouse, production, montage section, and a staff including 120 people, the questionnaire was distributed among 50 individuals.

\subsection{Results}

The Kolmogorov-Smirnov test was used to determine the data distribution frequency. Parametric statistical tests are used when data are normal, and non-parametric are applied if data are not normal. Data were tested in the context of this hypothesis:

$\sqrt{ } \quad$ Null hypothesis: data frequency follows normal distribution.

$\sqrt{ }$ Alternative hypothesis: data frequency does not follow normal distribution.

Significance level calculated for all factors was higher than $5 \%$, thus, it can be accepted that data are normal in all dimensions $(p<0.05)$. Based on the normality of data distribution, parametric statistical methods were used for data analysis. Moreover, mean difference tests were applied to determine the most influencing factor in achieving competitive advantage. The Friedman test was used to rate the factors affecting competitive advantage achievement from experts' viewpoint.

\subsection{Rating of Factors Based on Experts' Comments}

To compare the comments of the Toos Niroo technical firm's experts, the factors are rated based on the Friedman test, and the results are presented in Table 1.

Null hypothesis: different criteria have identical rates.

Alternative hypothesis: at least two criteria have different rates.

Table 1. Rating of competitive advantage factors in new product development based on the Friedman test according to experts' comments.

\begin{tabular}{lcc}
\hline Effective Factors in Achieving Competitive Advantage & Dimension & Rate \\
\hline Mutual relation between marketing and research \& development sections & Innovation & 1 \\
Creation of commitment across the organization for accountability to the customers & Accountability & 2 \\
Improved quality for customer's satisfaction & Quality & 3 \\
High investment in innovation & Innovation & 4 \\
Entering new markets & Innovation & 5 \\
after sale services and providing suitable services & Accountability & 6 \\
Innovation in distribution & Innovation & 7 \\
Ability to hire competent employees & Innovation & 8 \\
Customer relation management & Accountability & 9 \\
Product rate & Efficiency & 10 \\
Customizing & Accountability & 11 \\
Customer's loyalty to brand & Efficiency & 12 \\
Training the employees to promote their skills & Efficiency & 13 \\
\hline
\end{tabular}

According to the resulting average rates, the Friedman test can be used to rate the dimensions as presented in Table 2. 
Table 2. Rating of competitive advantage dimensions based on Friedman test according to experts' comments.

\begin{tabular}{lc}
\hline \multicolumn{1}{c}{ Dimension } & Rate \\
\hline Quality & 1 \\
Innovation & 2 \\
Accountability & 3 \\
efficiency & 4 \\
\hline
\end{tabular}

\section{Factor Rating Based on Comments of Top Managers of the Toos Niroo Technical Firm}

After identifying the most important factors based on experts' comments, they were rated according to the top managers' comments. By distribution of questionnaires among top managers of the Toos Niroo technical firm, the way for identifying and rating the factors was paved. Thus, all matrices of pairwise comparisons had acceptable incompatibility rates (lower than 0.1). Pairwise comparison matrix and the related incompatibility rates are presented in Table 3. As noted by Qodsipour [38], Lin and Liang [17], the best way for integrating decision makers' comments is to apply the geometrical mean. We used Super Decision software in the present study.

Table 3. Matrix of pairwise compares competitive advantage factors related to new product development. Limit super matrix: this matrix is obtained by powering a large weighted matrix until the stability of this matrix is ensures. It means that values of all matrix columns are identical. In this matrix, values are item priorities (Sub-items are sub-factors affecting competitive advantage), which can be rated based on limit super matrix.

\begin{tabular}{ccccl}
\hline Accountability & Innovation & Efficiency & Quality & \\
\hline 0.84204 & 1.87245 & 0.14358 & 1 & Quality \\
0.36239 & 0.43559 & 1 & 0.87444 & Efficiency \\
0.25929 & 1 & 0.69658 & 0.1462 & Innovation \\
1 & 3.85672 & 2.75947 & 1.876 & Accountability \\
& & $\mathrm{CR}=0.0632$ & & \\
\hline
\end{tabular}

Regarding Table 4, it is observed that the most important factor of competitive advantage in the Toos Niroo technical firm was accountability; whereas the least important factor was innovation. According to the results, the main factors of competitive advantage in new product development were rated as follows:

$\sqrt{ }$ First place: accountability.

$\sqrt{ }$ Second place: quality.

$\sqrt{ }$ Third place: efficiency.

$\sqrt{ }$ Fourth place: innovation.

Table 4. Rating of main factors of competitive advantage.

\begin{tabular}{ccccccl}
\hline Quality & Efficiency & Accountability & Innovation & Criterion & Objective & \\
\hline 0 & 0 & 0 & 0 & 0 & 0 & Objective \\
0 & 0 & 0 & 0 & 0 & 1 & Criterion \\
0 & 0 & 0 & 0 & 0.157166 & 0 & Innovation \\
0 & 0 & 0 & 0 & 0.434936 & 0 & Accountability \\
0 & 0 & 0 & 0 & 0.183003 & 0 & Efficiency \\
& & & & 0.224849 & & Quality \\
\hline
\end{tabular}

Regarding the final weights of the factors presented in Table 5, they can be rated as follows:

1. Quality

2. Quick and suitable service 
3. Creation of commitment across the organization

4. Customer relation management

5. Customer's loyalty

6. Product rate

7. Training the employees for enhancing their abilities

8. Mutual relation between marketing and R \& D sections

9. Ability to hire competent employees

10. Entering new markets

11. High investment in innovation

12. Innovation in distribution

Table 5. Rating of competitive advantage factors in new product development.

\begin{tabular}{ccl}
\hline Final & Normalized & \multicolumn{1}{c}{ Factor } \\
\hline 0.5 & 1 & Criterion (experts' and top managers' comment) \\
0.018339 & 0.23337 & Mutual relation between marketing and R \& D sections \\
0.018156 & 0.23104 & Ability to hire competent employees \\
0.012935 & 0.16460 & High investment in innovation \\
0.011991 & 0.15259 & Innovation in distribution \\
0.017163 & 21840 & Entering new markets \\
0.64417 & 0.19621 & Creation of commitment across the organization \\
0.096694 & 0.44464 & Quick and suitable service \\
0.014323 & 0.06586 & Customization \\
0.042034 & 0.19329 & Customer relation management \\
0.028048 & 0.13752 & Training the employees for enhancing their abilities \\
0.028907 & 0.14174 & Product rate \\
0.034547 & 0.16939 & Customer's loyalty \\
0.112447 & 0.55135 & Quality \\
\hline
\end{tabular}

\section{Implication}

Based on the evaluation of the outcomes obtained, it is possible to summarize that against the closed innovation model, the open innovation model holds the view that a company does not necessarily attract the highest talent for innovation. Therefore, processes are required to ensure the flow of ideas across the company, because not all people working for the company are intelligent, and the geographical dispersion of knowledge is expanding. Innovation is constantly increasing in the field of technology, which is a global feature, and therefore brings more actors to the field [39], thus, companies cannot be innovative independently and as a result competitive advantage cannot be created. As a result, open innovation was referred to as a tool defined by the purposeful use of input and output flows of knowledge to accelerate innovation in its market, and so, the development of the use of internal knowledge in external markets is a strategic strategy.

However, the remarkable thing is that open innovation is beyond the mere use of external ideas and technologies. This model is, in fact, a change in the way of using, managing, recruiting, and even creating assets, which ultimately leads to improved knowledge in terms of efficiency, quality, customer responsiveness, and innovation in order to lead to product development. In an open innovation, the competitive environment gains advantages over other organizations. Open innovation is a comprehensive approach that systematically encourages and exploits a wide range of internal and external resources to create innovative and competitive opportunities that are carefully integrated into the utilization of the capabilities and resources of the corporation and through the various channels. It is suggested to be used as a tool for survival in today's turbulent and highly competitive environment. When using bench marking, for example, apply open innovation strategies, especially in work processes, so a firm can use it as a competitive advantage. 


\section{Discussion and Evaluation}

To achieve competitive advantage, the Toos Nirro firm, along with other companies in the electrical industry need to focus on four leading factors including efficiency, quality, innovation, and accountability to customers. It should be mentioned that in the present study, internal aspects of the firm were investigated to identify and rate competitive advantage factors in new product development. Thus, environmental factors should not be neglected. Regarding the high importance of innovation-based on experts' comments and a literature review-high attention should be paid to this factor in new product development. Quality and innovation are required factors for suitable accountability to customers. Since the top managers in this study paced accountability first place, with the experts' comments and literature review in mind, quality and innovation should be paid more attention so that suitable accountability will be achieved.

Author Contributions: Sanaz Soltani and Akram Sadat Hoseini conceived and designed the experiments; Akram Sadat Hoseini performed the experiments; Sanaz Soltani and Mohammad Mehdizadeh analyzed the data; Akram Sadat Hoseini contributed reagents/materials/analysis tools; Sanaz Soltani wrote the paper.

Acknowledgments: The publishing fee of this paper was supported by DGIST (DGIST-IT-18-01).

Conflicts of Interest: The authors declare no conflict of interest.

\section{References}

1. David, F. Strategic Management, 12th ed.; Cultural Researches Publication: Tehran, Iran, 2016.

2. Hill, C.W.L.; Jones, G.R. Strategic Management Theory; Houghton Mifflin Company: New York, NY, USA, 2007.

3. De Toni, A.; Tonchia, S. Strategic Planning and Firms Competencies. Int. J. Oper. Prod. Manag. 2003, 23, 947-976. [CrossRef]

4. Gabbar, H. Intelligent topology analyzer for improved plant operation. Ind. Manag. Data Syst. 2007, 107, 229-250. [CrossRef]

5. Tabarsa, G.; Rezaeian, A.; Nazarpouri, A. Designing and explaining a competitive intelligence model based on organizational intelligence in knowledge-based organizations. Executive Management Magazine, 30 May 2012; 38-44.

6. Albrecht, K. The Power of Minds at Work: Organizational Intelligence in Action; American Management Association: New York, NY, USA, 2010.

7. Keegan, W.J. Global Marketing Management, Abdulhamid Ebrahimi; Office of Cultural Research: Tehran, Iran, 2007.

8. Rumelt, R.P. What in the World is Competitive Advantage? 2003. Available online: http: / /nts2.ximb.ac.in/users/fac/Amar/AmarNayak.nsf/dd5cab6801f1723585256474005327c8 / Odbebe68d654f43e652578bc003d582a/\$FILE/What\%20is\%20C\%20A.pdf (accessed on 22 May 2018).

9. Zabieh, L.E. Processes and mechanisms of creating and maintaining sustainable competitive advantage. J. Financ. Serv. Market. Center. 2014, 21, 47-48.

10. Porter, M.E. The Competitive Advantage of Nations; Free Press: New York, NY, USA, 1990.

11. Saaty, T.L.; Vargas, L.G. Decision Making with the Analytic Network Process; Springer: Berlin, Germany, 2006.

12. Barney, J. Is the Resource-based View a useful perspective for Strategic Management research? Yes. Acad. Manag. Rev. 2001, 26, 41-56.

13. Thijs, N.; Staes, P. European Primer on Customer Satisfaction Management; European Institute of Public Administration: Slovenian, Portucal, 2008.

14. Gounaris, S.P.; Stathakopoulos, V.; Athanassopoulos, A.D. Antecedents to perceived service quality: An exploratory study in the banking industry. Int. J. Bank Mark. 2003, 21, 168-190. [CrossRef]

15. Chang, K.C.; Chen, M.C.; Hsu, C.L. Applying loss aversion to assess the effect of customers' asymmetric responses to service quality on post-dining behavioral intentions: An empirical survey in the restaurant sector. Int. J. Hosp. Manag. 2010, 29, 620-631. [CrossRef]

16. Ren, L.; Xie, G.; Krabbendam, K. Sustainable competitive advantage and marketing innovation with in firms. Manag. Res. Rev. 2010, 33, 79-89. [CrossRef] 
17. Lin, J.S.C.; Liang, H.Y. The Influence of Service environments on Customer Emotion and Service Outcomes. Manag. Serv. Qual. 2011, 21, 350-372. [CrossRef]

18. Chesbrough, H.; Vanhaverbeke, W.; West, J. (Eds.) Open Innovation: Researching a New Paradigm; Oxford University Press: New York, NY, USA, 2006.

19. Chesbrough, H.; Crowser, A. Beyond High Tech: Early Adopters of Open Innovation in Other Industries. RED Manag. 2006, 36, 229-236.

20. Vanhaverbeke, W.; Cloodt, M. Open Innovation in Value Networks. In Open Innovation Reaching a New Paradigm; Chesbrough, H., Vanhaverbeke, W., West, J., Eds.; Oxford University Press: Oxford, UK, 2006; pp. 274-296.

21. Simard, C.; West, J. Knowledge Networks and the Geographic Locus of Innovation. In Open Innovation: Researching a New Paradigm; Chesbrough, H., Vanhaverbeke, W., West, J., Eds.; Oxford University Press: Oxford, UK, 2006; pp. 220-240.

22. Vanhaverbeke, W. The Inter-Organizational Context of Open Innovation. In Open Innovation: Reaching a New Paradigm; Chesbrough, H., Vanhaverbeke, W., West, J., Eds.; Oxford University Press: Oxford, UK, 2006.

23. Chesbrough, H. Open Innovation: A New Paradigm for understanding Industrial Innovation. In Open Innovation: Reaching a New Paradigm; Chesbrough, H., Vanhaverbeke, W., West, J., Eds.; Oxford University Press: Oxford, UK, 2006; pp. 15-33.

24. Huizingh, E. Open Innovation: State of the Art and Future Perspectives. Tecnovation 2011, 31, 2-9. [CrossRef]

25. Ocass, A.; Ngo, L.V. Winning through innovation and marketing: Lessons from Australia and Vietnam. Ind. Mark. Manag. 2011, 40, 1319-1329. [CrossRef]

26. Amara, N.; Landry, R. Sources of Information as Determinants of novelty of Innovation in Manufacturing Firms: Evidence from the 1999 Statistics Canada innovation Survey. Technovation 2005, 25, 245-259. [CrossRef]

27. Arora, A.; Fosfuri, A.; Gambardella, A. Markets for Technology: The Economics of Innovation and Corporate Strategy; MIT Press: Cambridge, MA, USA, 2001.

28. Gassmann, O.; Reepmeyer, G. Organizing pharmaceutical innovation: From science-based knowledge creators to drug-oriented knowledge brokers. Creat. Innov. Manag. 2005, 14, 233-245. [CrossRef]

29. Almirall, E.; Casadesus-Masanell, R. Open versus closed innovation: A model of discovery and divergence. Acad. Manag. Rev. 2010, 35, 27-47.

30. Shimizu, H.; Hoshino, Y. Collaboration and Innovation Speed: Evidence from a Prize Data-Set. 1955-2010; IIR Working Paper WP\#15-04; Institute of Innovation Research, Hitotsubashi University: Tokyo, Japan, 2015.

31. Rezaian, A.; Lashkar, B.M. Competitive intelligence and strategic decision making. J. Bus. Manag. Outlook 2010, 2, 166-169.

32. Barclay, Y.; Zon, D.; Holread, P. New Product Development (NPD); Ebrahimi, A.; Mahdieh, O., Translators; Homa Danesh Publications: Tehran, Iran, 2006.

33. Qarcheh, M.; Aleme Tabriz, A.; Karampour, A. A Model for determining effective factors on export performance based on the competitive strategy for distinction in non-metallic mineral industry. J. Strateg. Manag. Stud. 2011, 6, 119-140.

34. Sarv Niroo Tous. 1996. Available online: http://www.sarvnirootous.com/ (accessed on 9 August 2012).

35. Naderi, A.; Seif Naraghi, M. Research Methodology and Its Evaluation in Human Science by Emphasizing on Training Science, 4th ed.; Badr: Tehran, Iran, 2012.

36. Hafeznia, M.R. An Introduction on Research Methodology in Human Science; SAMT Publication: Tehran, Iran, 2016; Volume 13.

37. Sarmad, Z.; Bazargan, A.; Majazi, A. Research Methodology in Behavioral Science; Agah Publication: Tehran, Iran, 2016; Volume 1.

38. Qodsipour, H. Analytical Hierarchy Process (AHP); University of Amir Kabir: Tehran, Iran, 2016.

39. Moshadi, A.; Taghavi, Z. Innovation the Most Outstanding Competitive Advantage of Companies in the Market. In Proceedings of the 10th Conference of the Iranian Aerospace Society, Tehran, Iran, 1-3 March 2011.

(C) 2018 by the authors. Licensee MDPI, Basel, Switzerland. This article is an open access article distributed under the terms and conditions of the Creative Commons Attribution (CC BY) license (http://creativecommons.org/licenses/by/4.0/). 